CASSOWARY volume 4 (1): 10-18

ISSN : 2614-8900

E-ISSN : 2622-6545

Program Pascasarjana Universitas Papua, https://pasca.unipa.ac.id/

\title{
Keragaman genetik Anggrek Grammatophyllum scriptum asal biji dari hasil Kultur In Vitro berdasarkan penanda RAPD
}

\author{
Zarima Wibawati, Amelia Sarungallo, Barahima Abbas* \\ Program Pascasarjana dan Fakultas Pertanian Universitas Papua \\ Jl. Gunung Salju Amban Manokwari \\ *Email: barahimabas@gmail.com
}

\begin{abstract}
ABSTRAK: Propagation through tissue culture by using orchid seed as explants will produce a lot of orchid plants. This study aims to measure the genetic character of orchid plantlets that were regenerated from seeds which have been resulted from in vitro culture. The genetic character of the original orchid plants produced from in vitro culture was determined using Random Amplified Polymorphic DNA (RAPD) molecular markers. The results showed that the primers used in the RAPD analysis showed a polymorphic band pattern of 14 DNA bands, with sizes between $500 \mathrm{bp}-8000 \mathrm{bp}$. The genetic distance of Grammatophyllum scriptum orchids that was regenerated from seeds is between 0.229 and 0.649 . The progenis produced from in vitro culture were clustered into seven groups at a dissimilarity coefficient of $45 \%$.
\end{abstract}

Keywords : Orchid seed, Grammatophyllum scriptum, genetic diversity, invitro culture, plantlet

\section{PENDAHULUAN}

Anggrek merupakan salah satu tanaman hortikultura yang banyak diminati karena keindahan bunganya. Anggrek termasuk dalam famili Orchidaceae. Famili ini merupakan famili bunga-bungaan yang paling besar dan banyak digunakan sebagai bunga potong. Di Indonesia banyak jenis tumbuhan yang termasuk dalam tumbuhan epifit. Tumbuhan epifit adalah tumbuhan yang hidupnya menempel pada tumbuhan inang, salah satunya adalah anggrek. Spesies anggrek yang ada di Indonesia mempunyai potensi yang dapat dipakai sebagai induk silang dan unggul (Sandra, 2003).

Indonesia memiliki keragaman spesies anggrek yang banyak yaitu sekitar 5000 spesies yang tersebar di hutan-hutan Indonesia. Kelestarian keanekaragaman anggrek mulai terancam akibat banyaknya penebanganpenebangan liar yang tidak bertanggung jawab dan menyebabkan beberapa spesies anggrek terancam punah, salah satunya yaitu anggrek Grammatophyllum scriptum. Untuk menghindari adanya kepunahan harus dilakukan pelestarian. Salah satu cara untuk melestarikan yaitu dengan melakukan perbanyakan (Lestari et al., 2013).

Grammatophyllum merupakan salah satu jenis tanaman anggrek yang memiliki beberapa jenis yaitu Grammatophyllum scriptum, Grammatophyllum speciosum dan Grammatophyllum stapeliaeflorum, yang paling terkenal adalah anggrek 
Grammatophyllum scriptum. Anggrek ini paling terkenal di daerah Papua dan Maluku dengan sebutan anggrek macan (Shalifah, 2011).

Anggrek Grammatophyllum scriptum memiliki potensi yang besar dalam bidang bisnis. Potensi produksi anggrek ini lebih tinggi jika di bandingkan dengan tanaman hias lainnya. Produksi anggrek pada tahun 2015 sebesar 21.514.789 tangkai dan pada tahun 2016 produksi tanaman anggrek mengalami penurunan yaitu sebesar 19.978.078 tangkai (BPS, 2016).

Anggrek mempunyai peran penting dalam bidang pertanian, yaitu nilai ekonomi yang tinggi serta warna bunga yang menarik dan bentuknya unik, sehingga mempunyai daya tarik sendiri. Widiastoety et al., (2010) menyatakan bahwa anggrek banyak diminati oleh konsumen dari dalam negeri maupun dari luar negeri, karena keunikan karakter yang khas dapat menjadikan anggrek dalam rangkaian bunga potong yang tidak dapat digantikan oleh bunga lain. Daya tahan kesegaran bunga yang dimiliki anggrek termasuk dalam daya tahan yang begitu lama jika di bandingkan dengan bunga potong lainnya seperti mawar, anyelir dan gladiol.

Banyak konsumen yang tertarik pada anggrek karena anggrek ini sangat mudah beradaptasi di dataran rendah, perawatannya tidak terlalu sulit walaupun anggrek tumbuh dengan lambat, dan mudah berbunga jika dibandingkan dengan jenis tanaman lainnya. Jika tanaman anggrek Grammatophyllum scriptum sudah berbunga maka keindahan dari anggrek ini sudah dapat dinikmati oleh banyak konsumen (Suradinata et al., 2016). Keistimewaan anggrek Grammatophyllum scriptum yaitu mempunyai warna dasar hijau dengan totol - totol coklat yang mirip seperti warna macan dan memiliki habitus yang tegap dan kuat (Markal et al., 2015).

Menurut Isda et al., (2014), pengembangbiakan anggrek secara alami menggunakan biji sangat sulit karena biji anggrek tidak memiliki endosperm sebagai cadangan energi untuk pertumbuhan embry.

Perbanyakan Grammatopyhllum scriptum dengan menggunakan biji dapat dilakukan dengan menggunakan teknik kultur jaringan sehingga tanaman yang dihasilkan lebih banyak dalam waktu yang singkat dan bisa bebas dari penyakit. Biji anggrek bersifat mikroskopis dan tidak memiliki endosperm dapat diperbanyak melalui kultur in vitro dengan tingkat keberhasilan yang tinggi. Biji yang di kulturkan secara in vitro dengan sendirinya merupakan sumber keragaman genetik karena merupakan hasil persilangan yang terjadi secara alami.

Pengukuran tingkat variasi bibit yang berasal dari biji dapat diukur berdasarkan penanda morfologi dan molekuler. Teknik molekuler memiliki tingkat akurasi yang jauh lebih tinggi jika di bandingkan dengan teknik konvesional (Anggereini, 2008).

\section{METODE PENELITIAN}

\section{Bahan Tanaman dan Ekstraksi DNA}

Bahan yang digunakan dalam penelitian ini adalah planlet anggrek Grammatophyllum scriptum asal biji yang telah ditumbuhkan melalui kultur in vitro. Ekstraksi DNA dilakukan dengan menggunakan Genomic DNA mini kit (plant) GENEID. Metode yang isolasi DNA sesuai dengan metode yang digunakan oleh Abbas (2017). DNA genom diekstraksi dari planlet daun anggrek dengan cara digerus hingga daun anggrek menjadi halus. Bubuk hasil 
gerusan di pindahkan ke dalam tube 1,5 $\mathrm{ml}$ sebanyak $25 \mathrm{mg}$. Campurkan GPX1 buffer sebanyak $400 \mu$ l dan $5 \mu$ l RNAse yang ditambahkan ke dalam tube menggunakan vortex dan spiner. Campuran tersebut di inkubasi pada suhu $60^{\circ} \mathrm{C}$ selama 10 menit. Saat inkubasi dilakukan, elution buffer dipanaskan menggunakan heat block. GP2 buffer sebanyak $100 \mu$ l ditambahkan ke dalam campuran dan kemudian dihomogenkan dengan menggunakan vortex, kemudian diinkubasikan ke dalam freezer selama 3 menit. Campuran tersebut dipindahkan ke dalam kolom filter yang dipasang dalam tube $2 \mathrm{ml}$, kemudian disentrifuges dengan kecepatan $5000 \mathrm{rpm}$ selama 1 menit. Supernatant pada tube $2 \mathrm{ml}$ dipindahkan dengan hati-hati ke dalam tube $1,5 \mathrm{ml}$ yang baru. Volume lysate pada GP3 buffer 1,5 kali di tambahkan dan divortex selama 5 detik. Campuran $700 \mu \mathrm{l}$ dipindahkan ke dalam kolom GD yang telah diletakkan pada tube $2 \mathrm{ml}$, kemudian disentrifuges dengan kecepatan 15000 rpm selama 2 menit. Cairan yang keluar dari tube di buang dan sisa campuran dimasukkan ke dalam kolom GD, kemudian disentrifuge pada kecepatan 15000 rpm selama 2 menit. Cairan yang keluar di buang dan kolom GD yang digunakan diletakkan pada tube $2 \mathrm{ml}$. W1 buffer $400 \mu \mathrm{l}$ ditambahkan pada saat kolom dicuci dan kemudian disentrifuge dengan kecepatan 15000 rpm selama 30 detik. Buffer pencuci 600 $\mu l$ ditambahkan pada kolom yang dicuci setelah filtrate dibuang, dan disentrifuge pada 15000 rpm selama 30 detik. Kolom GD di keringkan dengan menggunakan disentrifuge selama 3 menit pada kecepatan 15000 rpm dan filtrat dibuang. Pindahkan kolom GD yang telah kering pada tube 1,5 ml dan Elution Buffer 100 $\mu \mathrm{l}$ ditambahkan, kemudian biarkan selama 4 menit hingga Elution Buffer terserap oleh matriks. Sentrifuge pada kecepatan 15000 rpm selama 30 detik untuk mendapatkan DNA yang murni.

\section{Uji Kualitas DNA}

Uji kualitas dan kuantitas DNA dilakukan dengan menggunakan spektrofotometer Nanodrop 2000 dengan mengukur kualitas DNA pada panjang gelombang $\lambda 260 \mathrm{~nm}$ dan panjang gelombang $\lambda 280 \mathrm{~nm}$.

SB buffer $1 \mathrm{x}$ dan agarose sebagai media penyangga dapat digunakan pada pengujian DNA. Agarose dibuat dengan cara menimbang agarose sebanyak 0,45 gram kemudian tambahkan $45 \mathrm{ml} \mathrm{SB}$ buffer. Campuran tersebut dipanaskan hingga jernih dan tuangkan ke dalam cetakan gel elektroforesis dengan sisir yang telah diletakkan didalamnya.

Masukkan gel yang sudah dipanaskan ke dalam tangki elektroforesis, dan tambahkan SB buffer hingga gel terendam seluruhnya. Sisir yang telah membentuk sumur-sumur, diisi dengan loading dye yang telah dicampur ekstrak DNA. Setiap $4 \mu$ diambil dari ekstrak DNA dan dicampur dengan loading dye sebanyak $1 \mu \mathrm{l}$. Bagian tepi gel dari sisir diisi dengan marker $1 \mathrm{~kb}$ DNA ladder sebanyak $4 \mu$ l. Tutup tangki elektroforesis dan diatur menggunakan tegangan $110 \mathrm{~V}$ selama 25 menit. Rendam gel ke dalam etidium bromide selama 15 menit, kemudian bilas dengan air dan divisualisasi menggunakan UV transiluminator.

\section{Amplifikasi DNA dengan Mesin PCR}

Volume reaksi amplifikasi sebanyak $10 \mu \mathrm{l}$, yang terdiri atas $2 \mu \mathrm{l}$ DNA genom, $5 \mu \mathrm{l}$ Master mix. $1 \mu \mathrm{l}$ primer dan $2 \mu \mathrm{l}$ GoTaq Green (Promega) merupakan sampel dari Master mix. Primer RAPD yang digunakan beserta urutan nukleotidanya disajikan pada Tabel 1 . 
Tabel 1. Daftar Primer RAPD yang digunakan dalam penelitian ini

\begin{tabular}{cc}
\hline Primer & $\begin{array}{c}\text { Urutan Nukleotida } \\
\left(5^{\prime}-3^{\prime}\right)\end{array}$ \\
\hline OPE 16 & GGT GAC TGT G \\
OPF 02 & GAG GAT CCC T \\
OPG 11 & TGC CCG TCG T \\
\hline
\end{tabular}

\section{Elektroforesis produk PCR}

Menggunakan gel agarosa $1 \%(\mathrm{~b} / \mathrm{v})$ dan lartan TAE buffer 1x. Agarose $1 \mathrm{~g}$ dilarutkan ke dalam $100 \mathrm{ml}$ TAE buffer untuk membuat gel agarosa. Elektroforesis dilakukan pada tegangan $95 \mathrm{~V}$ selama 2 jam. Gel yang mengandung fragmen DNA setelah mengali pemisahan direndam ke dalam larutan ethidium bromide selama 25 menit dan dibilas dengan air kemudian di visualisasi dengan menggunakan UV transiluminator. Dokumentasi dilakukan dengan menggunakan kamera digital.

\section{Analisis Data}

Data penampakan karakter genetik dan hasil skoring pita DNA (bands) dianalisis menggunakan analisis multivariate dengan metode Unweight Pair Group Method with Arithmatic (UPGMA) program NTsys versi 2.02 (Rohlf, 1998).

\section{HASIL DAN PEMBAHASAN}

\section{Keragaman genetik $G$. scriptum berdasarkan penanda RAPD}

Hasil uji kualitas dan kuantitas DNA tanaman anggrek $G$. scriptum yang telah diisolasi dengan menggunakan Genomic DNA mini kit disajikan pada Tabel 2. Uji kualitas DNA tanaman anggrek yang paling tinggi konsentrasinya yaitu sampel P21 sebanyak 327,8 ng/ $\mu \mathrm{l}$, sedangkan yang paling terendah konsentrasinya yaitu sebesar 8,3 ng/ $\mu \mathrm{l}$ pada sampel P14. DNA berkualitias memiliki nilai antara 1,8 sampai 2,0 pada rasio $\lambda 260$ dan $\lambda 280$ (Kundu 2011). Berdasarkan pengujian kualtias DNA yang telah dilakukan menunjukkan bahwa nilai pengukuran UV-transiluminator antara 1,77 - 2,08 untuk semua sampel DNA. Hal tersebut menunjukkan bahwa DNA hasil ekstraksi dapat dinyatakan murni karena kalau dibulatkan nilai pengukuran UVtransilluminator sampai pada angka satu decimal, maka semua sampel ekstrasi DNA berada pada kisaran 1.8-2.0 (Tabel 2). Kemurnian DNA yang digunakan sebagai template untuk PCR sangat dipengaruhi oleh kemurnian DNA yang digunakan (Sembiring et al. 2015).

Analisis keragaman genetik dilakukan dengan menggunakan tiga macam primer yaitu OPE16, OPF02 dan OPG11. Hasil amplifikasi DNA genom dari 12 bibit anggrek menghasilkan 14 pita polimorfik dan 5 pita monomorfik dengan ukuran berkisar 500 bp -8000 bp. Ketiga primer yang digunakan pada penelitian ini menunjukkan bahwa primer OPE16, OPF02 dan OPG11 menghasilkan pola pita polimorfik. Primer OPG11 menghasilkan pola pita polimorfik paling banyak yaitu tujuh pola pita DNA. Primer OPE16 merupakan primer yang menghasilkan pola pita polimorfik paling sedikit sebanyak dua pola pita DNA. Pita DNA monomorfik tertinggi dihasilkan oleh primer OPF02 yaitu sebanyak tiga pita DNA (Tabel 3). Penampilan pemisahan DNA hasil elektroforesis disajikan pada Gambar 1. Polimorfisme pita DNA yang dihasilkan pada penelitian ini menggunakan penanda RAPD menghasilkan keragaman genetik antara tanaman anggrek. Hasil penelitian ini sejalan dengan penelitian Hartati (2015) yang menyatakan bahwa penanda RAPD yang digunakan untuk tanaman anggrek terdapat keragaman genetik. 
Tabel 2. Hasil uji kualitas DNA tanaman Anggrek Grammatophyllum scriptum

\begin{tabular}{cccc}
\hline Sample ID & Konsentrasi DNA & Unit & Kualitas DNA (260/280) \\
\hline P01 & 35,1 & $\mathrm{ng} / \mu \mathrm{l}$ & 2,01 \\
P03 & 27,8 & $\mathrm{ng} / \mu 1$ & 1,94 \\
P04 & 27,7 & $\mathrm{ng} / \mu 1$ & 1,93 \\
P11 & 117,6 & $\mathrm{ng} / \mu 1$ & 2,00 \\
P13 & 84,9 & $\mathrm{ng} / \mu 1$ & 1,98 \\
P14 & 8,3 & $\mathrm{ng} / \mu 1$ & 2,08 \\
P21 & 327,8 & $\mathrm{ng} / \mu \mathrm{l}$ & 2,04 \\
P23 & 90,2 & $\mathrm{ng} / \mu 1$ & 1,92 \\
P24 & 13,1 & $\mathrm{ng} / \mu 1$ & 1,90 \\
P31 & $\mathrm{ng} / \mu 1$ & 2,05 \\
P32 & 277,6 & $\mathrm{ng} / \mu 1$ & 1,99 \\
P33 & 162,8 & $\mathrm{ng} / \mu 1$ & 1,77 \\
\hline
\end{tabular}

Tabel 3. Pola pita DNA hasil Amplifikasi dari tanaman anggrek G. scriptum hasil kultur in vitro yang teramplifikasi dengan menggunakan primer RAPD

\begin{tabular}{cccc}
\hline Primer & Jumlah pita polimorfik & Jumlah pita monomorfik & Total \\
\hline OPE 16 & 2 & 1 & 3 \\
OPF 02 & 5 & 3 & 8 \\
OPG 11 & 7 & 1 & 8 \\
\hline
\end{tabular}
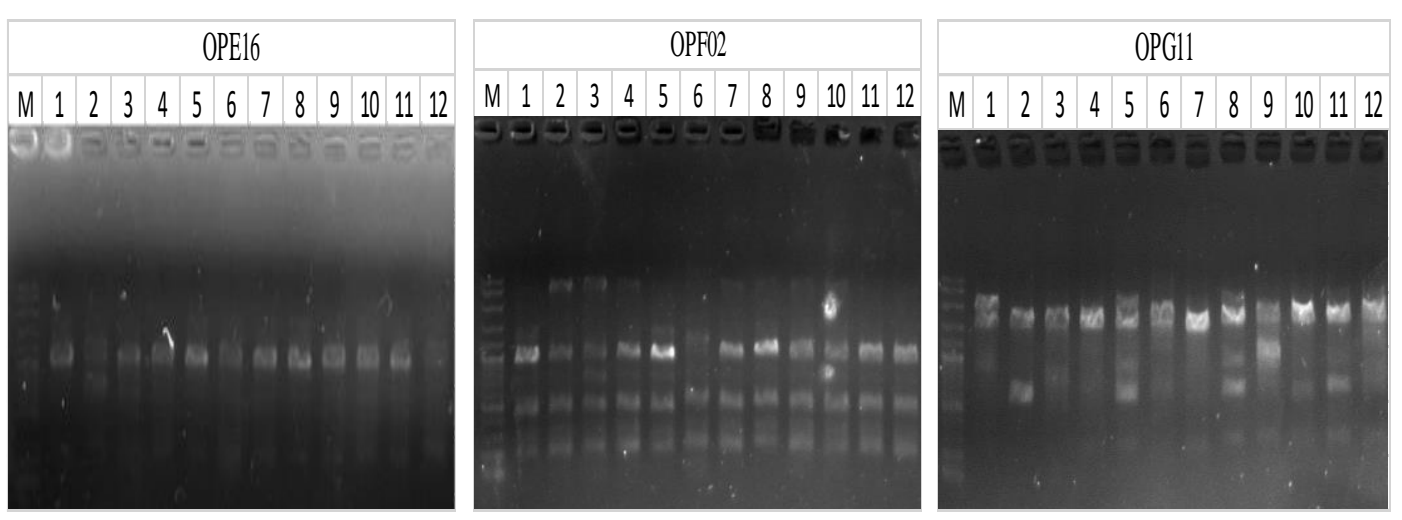

Gambar 1. Visualisasi fragmen-fragmen RAPD yang teramplifikasi dengan menggunakan primer OPE16, OPF02, dan OPG11. Angka 1-12 merupakan sampel tanaman, Marker $1 \mathrm{~kb}$ ladder $(\mathrm{M})$. 
Tabel . Ukuran pita DNA tanaman anggrek berdasarkan penanda RAPD pada tiga primer 4yang digunakan

\begin{tabular}{ccc}
\hline Primer & Jumlah pola pita & Ukuran pola pita (bp) \\
\hline OPE16 & 3 & $3000,2000,750$ \\
OPF02 & 8 & $8000,3500,3000,2500,1800,1000,750,500$ \\
OPG11 & 8 & $6000,4200,3100,2500,2000,1600,1400,600$ \\
\hline
\end{tabular}

Hasil skoring pita DNA setelah dielektroforesis yang kemudian dianalisis menggunakan program Ntsys menghasilkan ukuran jarak genetik antara 0.229 - 0,649 (Tabel 5). Konstruksi Dendrogram disajikan pada Gambar 2. Nilai koefisien disimilaritas antar sampel semakin besar maka hubungan kekerabatannya semakin jauh, begitu pula dengan sebaliknya nilai koefisien disimilaritas semakin kecil maka hubungan kekerabatannya semakin dekat.
Tanaman anggrak G. scriptum yang memiliki koefisien disimilaritas paling rendah yaitu P21 dengan P24 dan P21 dengan P31 dengan ukuran jarak genetik 0,229. Sampel tanaman anggrak G.scriptum yang memiliki koefisien disimilaritas tertinggi yaitu antara P01 dengan P11, P01 dengan P14, P03 dengan P13, P04 dengan P13, P04 dengan P14, P13 dengan P14, dan P13 dengan P33 dengan ukuran jarak genetik 0,649 .

Tabel 5. Matriks koefisien disimilaritas dari 12 sampel tanaman anggrek hasil kultur in vitro berdasarkan penanda RAPD

\begin{tabular}{|c|c|c|c|c|c|c|c|c|c|c|c|c|}
\hline & P01 & P03 & P04 & $\mathrm{P} 11$ & P13 & P14 & P21 & $\mathrm{P} 23$ & $\mathrm{P} 24$ & P31 & P32 & P33 \\
\hline P01 & 0.000 & & & & & & & & & & & \\
\hline P03 & 0,562 & 0.000 & & & & & & & & & & \\
\hline P04 & 0,562 & 0,459 & 0.000 & & & & & & & & & \\
\hline P11 & 0,649 & 0,562 & 0,459 & 0.000 & & & & & & & & \\
\hline P13 & 0,459 & 0,649 & 0,649 & 0,562 & 0.000 & & & & & & & \\
\hline P14 & 0,649 & 0,562 & 0,649 & 0,562 & 0,649 & 0.000 & & & & & & \\
\hline $\mathrm{P} 21$ & 0,562 & 0,459 & 0,459 & 0,324 & 0,562 & 0,562 & 0.000 & & & & & \\
\hline P23 & 0,513 & 0,513 & 0,607 & 0,513 & 0,397 & 0,607 & 0,397 & 0.000 & & & & \\
\hline $\mathrm{P} 24$ & 0,607 & 0,513 & 0,513 & 0,397 & 0,607 & 0,607 & 0,229 & 0,459 & 0.000 & & & \\
\hline P31 & 0,607 & 0,397 & 0,513 & 0,397 & 0,513 & 0,513 & 0,229 & 0,324 & 0,324 & 0.000 & & \\
\hline P32 & 0,513 & 0,513 & 0,607 & 0,513 & 0,397 & 0,513 & 0,397 & 0,324 & 0,459 & 0,324 & 0.000 & \\
\hline P33 & 0,562 & 0,562 & 0,459 & 0,459 & 0,649 & 0,562 & 0,459 & 0,607 & 0,513 & 0,513 & 0,513 & 0.000 \\
\hline
\end{tabular}




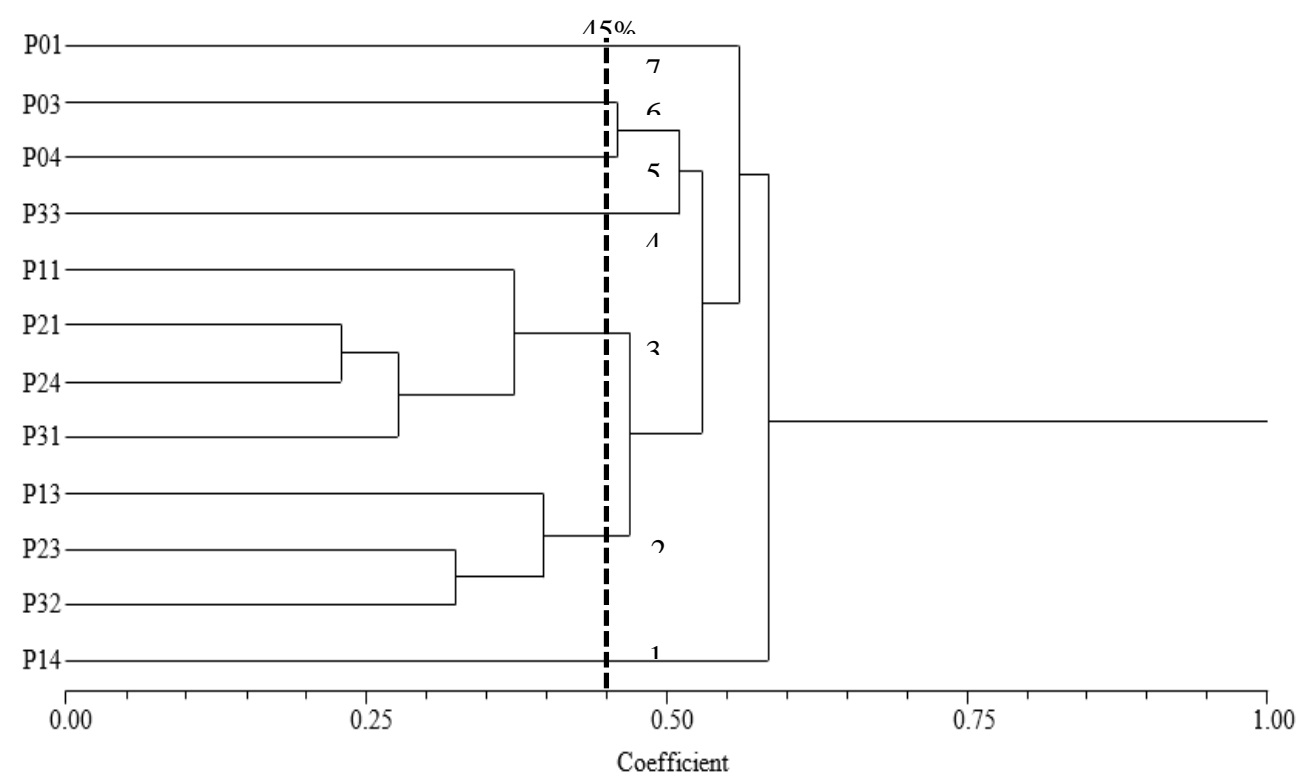

Gambar 2. Kontruksi dendogram dari 12 sampel anggrek G. scriptum hasil kultur in vitro berdasarkan penanda RAPD

Pengelompokkan tanaman anggrek berdasarkan penanda RAPD ditampilkan dalam bentuk dendogram (Gambar 2). Tanaman anggrek mengelompok ke dalam 7 kelompok pada koefisien disimilaritas $45 \%$. G. scriptum $\mathrm{P} 01$ berada pada kelompok satu, G. scriptum P03 berada pada kelompok dua, $G$. scriptum P04 berada pada kelompok tiga, G. scriptum $\mathrm{P} 13$ berada pada kelompok empat, G. scriptum P11, P21, P24, dan P31 berada pada kelompok lima, G. scriptum P13, P23, dan P32 berada pada kelompok enam, dan $G$. scriptum P14 berada pada kelompok tujuh. Pengelompokan seperti tersebut juga dijumpai pada tanaman sagu yang ditumbuhkan dari beiji menghasilkan keragaman yang tinggi (Riyanto et al. 2018). Secara alami bukan saja tanaman anggrek yang mengalami variasi genetik yang tinggi, tetapi juga tanaman sagu ditemukan mengalami variasi genetic yang tinggi pada penggunakan marker RPAD (Abbas et al. 2009; Abbas et al. 2009; Abbas 2018)

\section{KESIMPULAN}

Tiga primer yang digunakan dalam analisis RAPD menunjukkan pola pita polimorfis sebanyak 14 pita DNA, dengan ukuran berkisar 500 bp -8000 bp. Progeni tanaman anggrek $G$. scriptum beragam dengan jarak genetik antara $0.000-0.649$. Progeni yang dihasilkan anggrek G. scriptum dari kultur in vitro mengelompok membentuk tujuh kelompok pada koefisien dissimilarity $45 \%$.

\section{DAFTAR PUSTAKA}

Abbas, B., Dailami, M., Listyorini, F. and Munarti. 2017. Genetic Variations and Relationships of Papua's Endemic Orchids Based on RAPD Markers. Natural Science, 9, 377-385. doi: 10.4236/ns.2017.911035.

Abbas B. 2018. Sago palm genetic resource diversity in Indonesia. In: Ehara H, Toyoda Y, Johnson D (eds.). Sago Palm: Multiple Contributions to Food Security 
and Sustainable Livelihoods. Springer, Singapore. DOI: 10.1007/978-981-10-5269-95.

Abbas B, Bintoro MH, Sudarosono, Surahman M, Ehara H. 2009. Genetic relationship of sago palm (Metroxylon sagu Rottb.) in Indonesia based on RAPD markers. Biodiversitas 10 (4): 168-174. DOI: 10.13057/biodiv/d100402.

Abbas B, Bintoro MH, Sudarosono, Surahman M, Ehara H. 2009. Hirarki dan Diferensiasi Genetik Tanaman Sagu di Indonesia Berdasarkan Penanda RAPD. Zuriat, Vol. 20, No. 1, 8 JanuariJuni 2009

Anggereini, E. 2008. Random Amplified Polymorphic DNA (RAPD), suatu metode analisis DNA dalam menjelaskan berbagai fenomena biologi. Jurnal Biospecies 1(2): 73-76.

BPS. 2016. Tanaman Hias Indonesia. Produksi Anggrek Indonesia 2015-2016.

Baroroh, A. 2016. Analisis Kandungan Unsur Hara Makro Pada Pupuk Kompos Dari Serasah Daun Bambu dan Limbah Padat Pabrik Gula (Blotong). [Skripsi] Fakultas MIPA Universitas Sebelas Maret.

Hartati, S. 2015. Analisis keragaman genetik tetua dan hasil persilangan anggrek hitam (Coelogyne pandurata Lindl.). [Disertasi] Program Doctor Ilmu Pertanian Universitas Sebelas Maret Surakarta.

Isda, M. N. dan S. Fatonah. 2014. Induksi akar pada eksplan tunas anggrek Grammatophylum scriptum var. Citirum secara in vitro pada media ms dengan penambahan NAA dan BAP. Jurnal Biologi 7(2): 53-57.
Kundu. 2011. A simple ethanol wash of the tissue homogenates recovers high -quality genomic DNA from Corchorus species characterized by highly acidic and proteinaceous mucilages. Electron J Biotechnol.14: 1-7.

Lestari, E., T. Nurhidayati, dan S. Nurfadilah. 2013. Pengaruh konsentrasi ZPT 2,4-D dan BAP terhadap pertumbuhan dan perkembangan biji Dendrobium laxidlorum J.J Smith secara in vitro. Jurnal Sains dan Seni Pomits 2(1): 2337-3250.

Markal, A., M. N. Isda, dan S. Fatonah. 2015. Perbanyakan anggrek Grammatophylum scriptum (Lindl.) BL. melalui induksi tunas secara in vitro dengan penambahan BAP dan NAA. Jurnal FMIPA 2(1): 108-114.

Riyanto R, Widodo I, Abbas B. 2018. Morphology, growth and genetic variations of sago palm (Metroxylon sagu) seedlings derived from seeds. Biodiversitas 19: 682-688.

Rohlf, F.J. 1998. NTSYS-pc Numerical Taxonomy and Multivariate Analysis System. Version 2.02, Exter Sift Ware, New York

Sandra, E. 2003. Kultur Jaringan Anggrek Skala Rumah Tangga. AgroMedia Pustaka. Bogor.

Sembiring, I. M. S., L. A. P. Putri, dan H. Setiado. 2015. Aplikasi penanda lima primer RAPD (Random Amplified Polymorphic DNA) untuk analisis keragaman genetik andaliman (Zanthoxylum acanthopodium DC) Sumatera Utara. Jurnal Agroekoteknologi 4(1): 1748-1755

Shalifah, H. A. B., Muskhazli, Rusea, dan Nithiyaa. 2011. Variation in Mycorrhizal Specificity for In Vitro Symbiotic Seed 
Germination of

Grammatophyllum speciosum

Blume. Sains Malaysiana 40(5):

451-455.

Suradinata, Y. R., A. Nuraini, dan A.

Sela. 2016. Respon bunga

anggrek Dendrobium F1

(Dendrobium Malaysian Green)

pada berbagai konsentrasi

giberelin. Jurnal Kultivasi 15(1):

1-7.

Widiastoety, D., N. Solvia, dan M.

Soedarjo. 2010. Potensi anggrek

Dendrobium sp dalam

meningkatkan variasi dan

kualitas anggrek bunga potong.

Jurnal Litbang Pertanian 29(3):

101-106. 